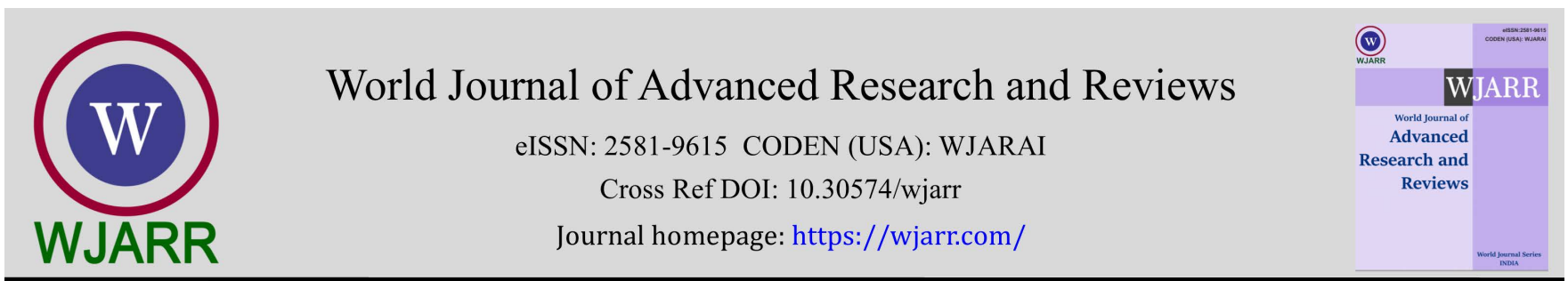

(RESEARCH ARTICLE)

Check for updates

\title{
Measuring the customers' brand loyalty towards fertilizers of An Giang Agrochemical Co, LTD
}

\author{
Dinh Van Khon ${ }^{1, *}$ and Nguyen Quoc Nghi ${ }^{2}$ \\ ${ }^{1}$ FPT Executive MBA Program, FPT University, Vietnam. \\ ${ }^{2}$ School of Economics, Can Tho University, Vietnam.
}

World Journal of Advanced Research and Reviews, 2022, 13(01), 811-817

Publication history: Received on 14 December 2021; revised on 19 January 2022; accepted on 21 January 2022

Article DOI: https://doi.org/10.30574/wjarr.2022.13.1.0063

\begin{abstract}
The study aims to determine the factors affecting the brand loyalty of customers to fertilizers of An Giang Agrochemical Co, Ltd (AGAC). The authors collected data from 190 customers who are using the fertilizer of AGAC. The study applies exploratory factor analysis and multivariable linear regression for analyses. The study has pointed out five factors positively impacting the brand loyalty towards fertilizer AGAC include product origin, brand, perceived price, product quality, and brand association. In which, the perceived price has the most influence on customer brand loyalty of customers to the fertilizer of AGAC.
\end{abstract}

Keywords: Brand loyalty; Customer; Fertilizer, An Giang Agrochemical Co, LTD

\section{Problem statement}

Customer brand loyalty is the extent that any business wants to achieve. Loyal customers help companies save costs, make more transactions, and have positive word-of-mouth (Kotler et al, 1989). If a company loses a customer, it means they not only lose revenue from that customer, but they may lose many more customers (Kotler and Keller, 2005). Moreover, it costs much for the company to regain the number of lost customers if they want to maintain the growth speed.

A Giang Agrochemical Co, Ltd was established on September 9, 2009, up to now, with a long history of growing, AGAC is now a company with products such as fertilizers, pesticides, and crop protection agents. During its operation, AGAC is proud to be a reliable manufacturer of distributors and agents across the country. Currently, AGAC's products have been distributed in all provinces in Vietnam. AGAC expects to export all products to Cambodia, Laos, and Thailand.

Mekong Delta region has a long-standing developed agricultural economy with rice as the main food crop. Currently, the progress of science and technology and the increase of intensive farming have increased pest pressure on crops. Therefore, the demand for fertilizer in agricultural production grows. Currently, the fertilizer market develops in both quantity and product types provided by different manufacturers. A large number of fertilizer brands in the market greatly influence the choice and loyalty of farmers. Therefore, research on the loyalty of farmers to fertilizer brands is essential for enterprises. To meet the goals and the orientation of AGAC, the study "Measuring customer's brand loyalty to fertilizer of An Giang Agrochemical Co, Ltd" is necessary. Also, the study proposes scientific and practical management implications to help orient and develop AGAC.

\footnotetext{
${ }^{*}$ Corresponding author: Dinh Van Khon

FPT Executive MBA Program, FPT University, Vietnam. 


\section{Theoretical framework and research model}

Loyalty is a deep commitment to repurchase or re-visit a preferred product/service in the future, thereby causing a repetition of the same brand or re-ordering, despite circumstances and marketing efforts that may lead to behavioral changes (Oliver, 2000). Customers are considered to be brand loyal when they tend to buy multiple products of a certain brand and repeat purchases (Chaudhuri Holbrook, 2001). Loyalty shows the attitude of customers, if they trust and have a good impression of a brand, they will prioritize buying products of that brand (Yoo et al, 2000). Loyalty behavior focuses on the customer's value to the brand (Schultz Bailey, 2000).

\subsection{The relationship between product origin and brand loyalty}

Country of origin is considered an important factor affecting customer attitudes and acceptance towards product brands (Nghi and Viet, 2011). In a study in 2010, Thimangu has said product origin affects customer brand loyalty. Research by Saydan (2013) has shown that product origin is not only an impacting factor to customer brand loyalty, but it has the highest impact level when compared to others components of brand value. Therefore, the study proposed hypothesis H1: Product origin positively affects customers' brand loyalty to fertilizer of AGAC.

\subsection{The relationship between product brand and loyalty}

Branding is a tool to connect a company's customers and suppliers, and to maintain long-run relationships with the two parties (Chang and Chieng, 2006). Brands influence and assist customers in choosing a good product to satisfy their needs or demands. Yee and Yahyah (2008) have demonstrated that brand characteristics influence brand loyalty. Research by Thao (2014) has argued that product brand has a positive and important correlation to customer loyalty to that brand. Thus, the study suggested the hypothesis H2: Product brand positively affects customer's brand loyalty towards fertilizer of AGAC.

\subsection{The relationship between perceived price and brand loyalty}

If a product's perceived value is higher than its price, the customer will buy that product. Perceived price influences customers' choice preferences and decision to continue buying (Bucklin et al, 1998). The studies of Tuu (2007), Thao (2014) have confirmed the direct influence of perceived price on customer brand loyalty. From there, the study hypothesizes H3: Perceived price positively affects customers' brand loyalty towards fertilizer products of AGAC.

\subsection{The relationship between perceived quality and brand loyalty}

Perceived quality represents the customer's perception of the product quality that they expect about a brand. Perceived quality includes the quality of products and supplier-related services (Phuong, 2013). Researches by Thimangu (2010), Thao (2014) have demonstrated that perceived quality has a direct and positive influence on customer loyalty. Perceived quality influences brand loyalty (Yoo et al, 2000). The more loyal customers are to the brand, the more they believe that the brand will provide high-quality products (Ho Huy Tuu, 2007). Hence, the study proposes hypothesis H4: Perceived quality positively affects customer brand loyalty to fertilizer products of AGAC.

\subsection{Relationship between brand association and brand loyalty}

The brand association makes a difference, creates positive attitudes and feelings about the brand, and gives reasons to buy the product (Aaker, 1991). Brand loyalty results from customers' perception, that only one particular brand can satisfy their needs. Chin and Wen (2010) have shown the importance of brand association its great influence on brand loyalty. Similarly, Jan et al. (2013) have also confirmed the significance and strong impact of brand association on customers' brand loyalty. The study suggests hypothesis H5: Brand association positively impacts customers' brand loyalty to fertilizer products of AGAC.

Based on the literature review and research hypotheses, the research model is proposed as follows 


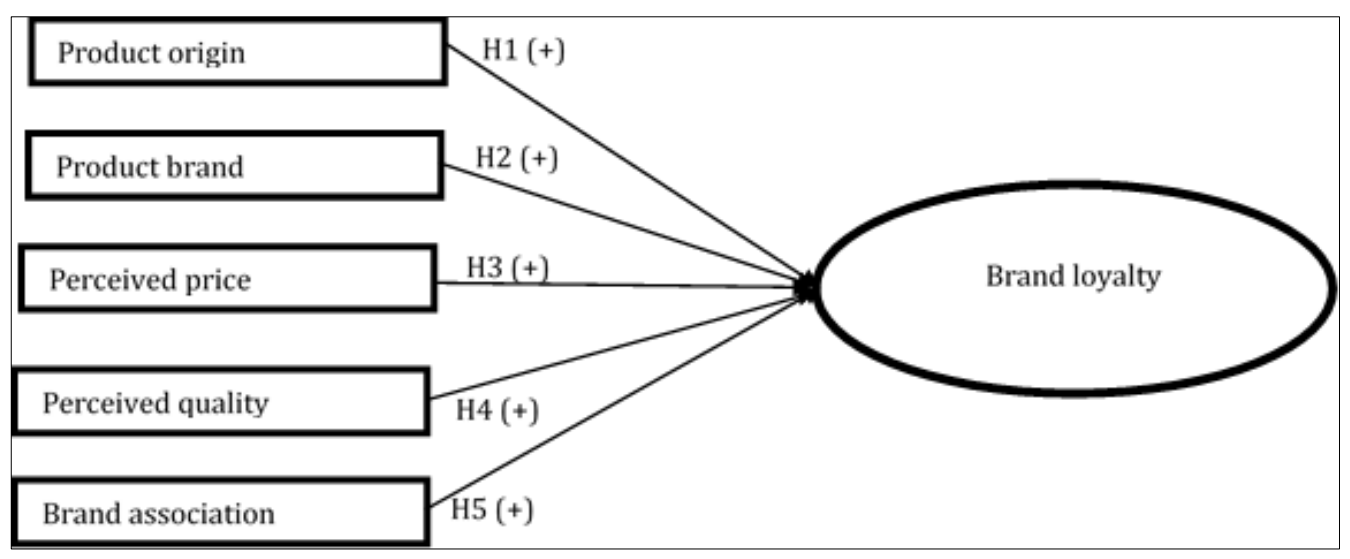

Figure 1 Proposed research model

Table 1 Interpretation of observed variables of the research model

\begin{tabular}{|c|c|c|c|}
\hline Factor & Observed variables & Scale & Reference resources \\
\hline \multirow{3}{*}{$\begin{array}{l}\text { Product origin } \\
\text { (PO) }\end{array}$} & $\begin{array}{l}\text { The origin of fertilizer products of AGAC is } \\
\text { reliable. }\end{array}$ & Likert 1-5 & \multirow{3}{*}{$\begin{array}{l}\text { Thimangu (2010), Nghi } \\
\text { and Viet (2011), Saydan } \\
\text { (2013) }\end{array}$} \\
\hline & $\begin{array}{l}\text { The origin of fertilizer products of AGAC is } \\
\text { prioritized for selection. }\end{array}$ & Likert 1-5 & \\
\hline & $\begin{array}{l}\text { The origin of fertilizer products of AGAC is } \\
\text { more reliable than other brands. }\end{array}$ & Likert 1-5 & \\
\hline \multirow{3}{*}{$\begin{array}{l}\text { Product brand } \\
\text { (PB) }\end{array}$} & $\begin{array}{l}\text { The fertilizer product brand of AGAC is well } \\
\text { known to many farmers. }\end{array}$ & Likert 1-5 & \multirow{3}{*}{$\begin{array}{l}\text { Punniyamoorthy and Raj } \\
\text { (2007), Yee and Yahyah } \\
\text { (2008), Thao (2014) }\end{array}$} \\
\hline & $\begin{array}{l}\text { The fertilizer product brand of AGAC creates } \\
\text { trust for farmers. }\end{array}$ & Likert 1-5 & \\
\hline & $\begin{array}{l}\text { The fertilizer product brand of AGAC is } \\
\text { distinguished from other brands. }\end{array}$ & Likert 1-5 & \\
\hline \multirow{3}{*}{$\begin{array}{l}\text { Perceived price } \\
\text { (PP) }\end{array}$} & $\begin{array}{l}\text { Fertilizer products of AGAC have reasonable } \\
\text { prices. }\end{array}$ & Likert 1-5 & \multirow{3}{*}{$\begin{array}{l}\text { Yee and Yahyah (2008), } \\
\text { Tuu (2007) }\end{array}$} \\
\hline & $\begin{array}{l}\text { The price of fertilizer products of AGAC is } \\
\text { stable and less changed compared with other } \\
\text { brands. }\end{array}$ & Likert 1-5 & \\
\hline & $\begin{array}{l}\text { Fertilizer products of AGAC are more } \\
\text { economical than other brands. }\end{array}$ & Likert 1-5 & \\
\hline \multirow{4}{*}{$\begin{array}{l}\text { Perceived } \\
\text { quality (PQ) }\end{array}$} & Fertilizer products of AGAC are high-quality. & Likert 1-5 & \multirow{4}{*}{$\begin{array}{l}\text { Thimangu (2010),Nghiem } \\
\text { (2012), Tuu (2007) }\end{array}$} \\
\hline & $\begin{array}{l}\text { Fertilizer products of AGAC are strictly tested } \\
\text { for quality. }\end{array}$ & Likert 1-5 & \\
\hline & $\begin{array}{l}\text { Using fertilizer products of AGAC ensures } \\
\text { health safety. }\end{array}$ & Likert 1-5 & \\
\hline & $\begin{array}{l}\text { Fertilizer products of AGAC have a higher } \\
\text { quality compared to other brands. }\end{array}$ & Likert 1-5 & \\
\hline \multirow{3}{*}{$\begin{array}{l}\text { Brand } \\
\text { association } \\
\text { (BA) }\end{array}$} & $\begin{array}{l}\text { When it comes to fertilizers, farmers } \\
\text { immediately think of AGAC's products. }\end{array}$ & Likert 1-5 & \multirow{3}{*}{$\begin{array}{l}\text { Yoo and Donthu (2000), } \\
\text { Chin and Wen (2010), Jan } \\
\text { et al. (2013) }\end{array}$} \\
\hline & $\begin{array}{l}\text { Farmers easily visualize the packaging and } \\
\text { color of AGAC's fertilizer products. }\end{array}$ & Likert 1-5 & \\
\hline & $\begin{array}{l}\text { When it comes to AGAC's fertilizers, farmers } \\
\text { immediately think of a reputable brand. }\end{array}$ & Likert 1-5 & \\
\hline
\end{tabular}




\begin{tabular}{|l|l|l|l|}
\hline \multirow{4}{*}{$\begin{array}{l}\text { Brand loyalty } \\
\text { (BL) }\end{array}$} & $\begin{array}{l}\text { Farmers think about AGAC when they have the } \\
\text { demand for fertilizers. }\end{array}$ & Likert 1-5 \\
\cline { 2 - 3 } & $\begin{array}{l}\text { Farmers will not buy other fertilizer brands if } \\
\text { AGAC's fertilizers are not available at the store. }\end{array}$ & Likert 1-5 & \\
\cline { 2 - 3 } & $\begin{array}{l}\text { Farmers are willing to pay more to use the } \\
\text { fertilizer products of AGAC. }\end{array}$ & Likert 1-5 & \multirow{2}{*}{ Aaker (1991), Nghiem } \\
\cline { 2 - 3 } & $\begin{array}{l}\text { Farmers continue to buy fertilizer products of } \\
\text { AGAC in the future. (2013) }\end{array}$ & Likert 1-5 \\
\cline { 2 - 3 } & $\begin{array}{l}\text { Farmers will recommend fertilizer products of } \\
\text { AGAC to others. }\end{array}$ & Likert 1-5 & \\
\hline
\end{tabular}

\section{Methodology}

\subsection{Analytical method}

The quantification of the factors affecting customers' brand loyalty towards AGAC's product is carried out in 3 steps. Step 1: Use Cronbach's Alpha to test the internal correlation between observed variables. Step 2: Using the exploratory factor analysis (EFA) to test the convergent and discriminant validity. Step 3: Use multivariable linear regression to test the research hypotheses.

\subsection{Data collection method}

The study uses convenient sampling to survey 190 customers who are using fertilizer products of AGAC. According to Hair et al. (1998), in EFA, the observation/ measurement variable proportion should be 5:1, meaning that 1 measurement variable requires at least 5 observations. Tabachnick and Fidell (2007) have confirmed that the suitable sample size for regression is determined to be $\mathrm{N} \geq 50+5 * \mathrm{~m}$ (where $\mathrm{m}$ is the number of independent variables). The above arguments show that the research sample size meets the reliability requirement for testing the research hypothesis.

\section{Research results and discussion}

\subsection{Scale reliability test}

Cronbach's Alpha coefficient helps eliminate "garbage" variables. Those with item-total correlation values less than 0.3 are excluded (Nunnally, 1978; Peterson, 1994) and the scale is satisfactory if it's Cronbach's Alpha is higher than 0.6 (Slater, 1995). Based on the result in table 2, the scales have high reliability (the minimum Cronbach's Alpha value is 0.8 ). Therefore, all variables are used in the EFA step.

Table 2 Scale reliability test result

\begin{tabular}{|l|c|c|}
\hline Observed variables & Corrected item-total correlation & Cronbach's alpha if item deleted \\
\hline \multicolumn{2}{|l|}{ Product origin: Cronbach's Alpha $\mathbf{= 0 . 8 7 3}$} & 0.831 \\
\hline P01 & 0.746 & 0.849 \\
\hline P02 & 0.726 & 0.784 \\
\hline P03 & 0.800 & 0.732 \\
\hline Product brand: Cronbach's Alpha $\mathbf{0 . 8 0 2}$ & 0.653 \\
\hline PB1 & 0.644 & 0.787 \\
\hline PB2 & 0.715 & \\
\hline PB3 & 0.589 & \\
\hline
\end{tabular}




\begin{tabular}{|l|c|c|}
\hline \multicolumn{2}{|c|}{ Perceived price: Cronbach's Alpha = 0.893} \\
\hline PP1 & 0.784 & 0.853 \\
\hline PP2 & 0.831 & 0.812 \\
\hline PP3 & 0.756 & 0.877 \\
\hline Perceived quality: Cronbach's Alpha $\mathbf{0 . 8 0 0}$ \\
\hline PQ1 & 0.672 & 0.719 \\
\hline PQ2 & 0.596 & 0.758 \\
\hline PQ3 & 0.637 & 0.738 \\
\hline PQ4 & 0.547 & 0.782 \\
\hline Brand association: Cronbach's Alpha $=\mathbf{0 . 8 5 5}$ & 0.804 \\
\hline BA1 & 0.720 & 0.781 \\
\hline BA2 & 0.748 & 0.808 \\
\hline BA3 & 0.717 & 0.904 \\
\hline Brand loyalty: Cronbach's Alpha $=\mathbf{0 . 9 3 0}$ & 0.919 \\
\hline BL1 & 0.867 & 0.912 \\
\hline BL2 & 0.792 & 0.928 \\
\hline BL3 & 0.827 & 0.906 \\
\hline BL4 & 0.741 & \\
\hline BL5 & 0.856 & \\
\hline
\end{tabular}

\subsection{Exploratory Factor Analysis (EFA)}

Base on the EFA for the independent variables in the research model, the results achieved are as follows: The significance level (Sig.) is less than 0.05 ; $\mathrm{KMO}=0.857$ in the range from 0 to 1 ; factor loading indicators of all observed variables are greater than 0.5 ; total variance extracted reaches $75.57 \%>50 \%$. This shows that the research data is consistent. Thus, the analysis results create 5 factors, including product origin ( 3 observed variables), product brand ( 3 observed variables), perceived price ( 3 observed variables), perceived quality ( 4 observed variables), and brand associations ( 3 observed variables). The observed variables belong to the factors as proposed by the model, so there is no change in their names. Similarly, the EFA for the dependent variable "Brand loyalty" gives satisfactory results: The significance level of the model (Sig.) is less than 0.05 and $\mathrm{KMO}=0.831$ in the range from 0 to 1 ; factor loading values of all observed variables are greater than 0.5 ; total variance extracted is $78.25 \%>50 \%$. This shows that the research data is consistent. The analysis results create one factor, "brand loyalty".

\subsection{Multivariate linear regression}

After the EFA, multivariable linear regression is used to determine the factors affecting customers' brand loyalty to fertilizer products of AGAC. The results are shown in Table 3.

Based on the above table, the model's adjusted $\mathrm{R}^{2}$ reaches $60.5 \%$, which proves that the brand loyalty towards fertilizer products of AGAC is well defined by the model. The Sig.F coefficient of the model is much smaller than the $\alpha=5 \%$, so the regression model is significant. Durbin-Watson $=1.474$ and VIF $<4$, which proves that the model does not have autocorrelation and multicollinearity. There are five independent variables with statistical significance. This shows that the factors of product origin, product brand, perceived price, product quality, and brand association have a positive impact on customers' brand loyalty to AGAC's fertilizers. In other words, if customers appreciate the origin, brand, perceived price, quality, and brand association of a product, then their brand loyalty improves. In which, the perceived price factor has the most impact on customer loyalty to fertilizer products of AGAC. 
Table 3 Multivariate linear regression result

\begin{tabular}{|l|c|c|c|}
\hline Factor & Standardized estimated value & Significance level (Sig.) & Hypothesis \\
\hline Product origin & 3.532 & 0.001 & H1: accepted \\
\hline Product brand & 3.153 & 0.002 & H2: accepted \\
\hline Perceived price & 4.716 & 0.000 & H3: accepted \\
\hline Perceived quality & 2.664 & 0.008 & H5: accepted \\
\hline Brand association & 4.201 & 0.000 & \\
\hline Adjusted R & 0.605 & & \\
\hline Durbin-Watson stat & 1.474 & & \\
\hline Sig.F & 0.000 & &
\end{tabular}

\section{Conclusion}

The study has demonstrated five factors that positively affect the brand loyalty of customers to fertilizer products: product origin, brand, perceived price, product quality, and brand associations. In which, the perceived price factor puts the strongest influence on the brand loyalty towards AGAC's fertilizer products. Based on the research results, several managerial implications are offered as follows: Firstly, improving the perceived value of customers for fertilizer products of AGAC. Secondly, improve the attributes related to the brand association of AGAC's fertilizers. Thirdly, strengthen customers' trust in the origin of fertilizer products. Fourthly, continuously improve the quality of products. Fifthly, strengthen the promotion activities and the brand awareness of fertilizer products.

\section{Compliance with ethical standards}

\section{Acknowledgments}

The researchers appreciated all the corrections suggested and recommended by the experts.

\section{Disclosure of conflict of interest}

The authors declare that there are no competing or potential conflicts of interest.

\section{References}

[1] Aaker DA. Managing brand equity. Capitalizing on the value of a brand name. New York: The Free Press. 1991.

[2] Bucklin RE, Gupta S, Siddarth, S. Determining segmentation in sales response across consumer purchase behaviors. journal of Marketing Research. 1998; 35(2): 189-197.

[3] Chang P, Chieng M. Building consumer-brand relationship: A cross-cultural experience view. Psychology Marketing. 2006; 23(11): 927-959.

[4] Chaudhuri A, Holbrook MB. The chain of effects from brand trust and brand affect to brand performance: the role of brand loyalty. Journal of Marketing. 2001; 65(2): 81-93.

[5] Chen CF, Tseng WS. Exploring customer-based airline brand equity: Evidence from Taiwan. Transportation Journal. 2010; 24-34.

[6] Hair JF, Tatham RL, Anderson RE, Black WC. Multivariate Data Analysis (5thed.). New Jersey: Prentice-Hall. 1998.

[7] Jan MT, Abdullah K, Smail MH. Antecedents of loyalty in the airline industry of Malaysia: An examination of the higher-order measurement model. In Proceedings of 3rd Asia-Pacific Business Research Conference. February 2013; 25-26. 
[8] Kotler A, Frank. Principles of Marketing (4th Ed.). Englewood Cliffs, NJ: Prentice-Hall. 1989.

[9] Kotler P, Keller K. Marketing Management (12th Ed.). Prentice-Hall. 2005.

[10] Nunnally, J. C. (1978). Psychometric Theory. New York: McGraw- Hill.

[11] Nghi, N. Q, Viet, L. Q. (2011). Customer behavior. Can Tho University Publishing House.

[12] Nghiem TT. Research on factors affecting the brand loyalty of customers to Nokia mobile phones. Master Thesis of Economics. University of Economics Ho Chi Minh City. 2012.

[13] Oliver RL. Customer satisfaction with service. Handbook of services marketing and management. 2000; 247-254.

[14] Peterson RA. A meta-analysis of Cronbach's coefficient alpha. Journal of consumer research. 1994; 21(2): 381391.

[15] Punniyamoorthy M, Raj MPM. An empirical model for brand loyalty measurement. Journal of targeting, measurement and analysis for marketing. 2007; 15(4): 222-233.

[16] Phuong NTB. Factors affecting customer brand loyalty: A case study of refrigerant product HCFC22.Master's Thesis in Economics. University of Economics Ho Chi Minh City. 2013.

[17] Saydan R. Relationship between the country of origin image and brand equity: An empirical evidence in England market. International Journal of Business and Social Science. 2013; 4(3): 78-88.

[18] Schultz DE, Bailey SE. Customer/brand loyalty in an interactive marketplace. Journal of Advertising Research. 2000; 40(3): 41-52.

[19] Slater SF. Issues in conducting marketing strategy research. Journal of Strategic Marketing. 1995; 3(4): 257-270.

[20] Tabachnick BG, Fidell LS. Using multivariate statistics (3rd ed.). New York: Harper Collins. 1996.

[21] Tuu HH. The impact of price and perceived quality on consumer satisfaction and loyalty to fish in Nha Trang City.Journal of Fisheries Science and Technology, Nha Trang Univesity. 2007; 1: 19-26.

[22] Thao TTN. Factors affecting brand loyalty of instant coffee in Ho Chi Minh City. Master's Thesis in Economics. University of Economics Ho Chi Minh City. 2014.

[23] Thimangu T. Country of origin effects and loyalty for cement brands in Uganda. Makerere University, Uganda. 2010.

[24] Yee WF, Yahyah S. Influence of Brand Loyalty on Consumer Sportswear. International Journal of Economics and Management. 2008; 2(2): 221-236.

[25] Yoo B, Donthu N, Lee S. An examination of selected marketing mix elements and brand equity. Journal of the academy of marketing science. 2000; 28(2): 195-211. 